UDC 631.445

\title{
THE ELEMENTARY SOIL AREAS \\ OF THE MYKOLAIV-HORODOK OPILLIA
}

\author{
Mykola Fedotikov, Taras Yamelynets
}

Ivan Franko National University of Lviv, P. Doroshenko St., 41, UA - 79007 Lviv, Ukraine

\begin{abstract}
During the investigation of soil structure of Mykoliv-Horodok Opillia we used the methods of detection (natural-cartometric, relief sculpture, quality-genetic) and interpretation (statistical cartometric, functional and analytical) of the soil structure. To characterize elementary soil areas of the key area the natural-cartometric method was used, it makes it possible to determine the parameters of the soil structure and obtain quantitative indicators for the key elementary soil areas (ESA) parameters, which are elementary soil areas composition and area ratio, complexity, fractionality, breakdown, heterogeneity and contrast range.

The article presents results of a study of qualitative and quantitative characteristics of elementary soil areas of the Mykolaiv-Horodok Opillia. The degree of variability of ESA areas was identified and analysed with coefficient of the differentiation of the soil outlines and methods of variation statistics. Form, degree of tortuosity and elongation of area limits using the coefficient of the dismemberment were studied. The character of outlines of elementary soil areas within the area of research was investigated. The basic features of ESA borders depending on various environmental factors are identified. Certain laws of changing of the basic parameters of elementary soil areas, which form the soil structure of Mykolaiv-Horodok Opillia were traced.

Key words: elementary soil area, structure of the soil cover, coefficient of variability of soil outlines, coefficient of the differentiation of the soil outlines, coefficient of the dismemberment of the soil boundaries.
\end{abstract}

Like any complex system, soil is made up of smaller parts. These initial, primary, smallest units are elementary soil areas (hereinafter ESA). According to V. Friedland, each ESA can be characterized by the following features: geometry (or shape), content (i.e., the ratio of soil or soils that make it up to a certain classification unit), conditions under which ESA was formed and its place in the smallest integrated heterogeneous soil units, which are soil combinations, typical of it only [9].

In order to investigate the soil structure of certain territory, we need to analyse and organize all of its components, from the smallest ones, that is, ESA. And, as mentioned above, ESA is characterized by a number of traits that differ not only objectively, by definition, but also by the specifics of interpretation and analysis.

The concept of the soil structure was formed in the early 70 s of the $20^{\text {th }}$ century by V. Friedland, who was the first one to write a monograph devoted entirely soil combinations and give a definition of soil structure as the areas of certain soils manifoldly and rhythmically repeated in space that create a well-established structure and pattern of soil, and stable mechanisms of geochemical and geographical links between soils that are in this structure. Also, system approach (which had just become popular due to the introduction of mathematical research methods to the science) allowed V. Friedland to give definition of the soil structure

(C) Fedotikov M., Yamelynets T., 2016 
smallest unit, i.e. elementary soil area: soils belonging to any classification unit of the lowest ranking which occupy the space from all other sides limited by other elementary soils or nonsoil formations [9]. Friedland's work was continued and supplemented by his disciple Y. Hodelman. Unlike V. Friedland, who used the SS term to refer to soil cover of any area only, Y. Hodelman believes that eventually there is another use of the word - to denote specific types of structures as taxonomic concept that involves regular alternation of a certain number of elementary units of soil characterized by common origin and development, certain geometric parameters and forming confined space areas. Each area is offered to be referred to as elementary structural soil area [9].

Various aspects of the soil mapping reflecting the structure of soil are considered in a large number of works. These are works by V. Friedland [8, 9], Y. Hodelman [2], N. Strohanova [7], L. Prasolov. [4], O. Haskevych [1], V. Radzii [5, 6], S. Pozniak, Ye. Krasieha, M. Kit [3] and many others. The scientists have analysed the impact of soil differentiation factors on the formation of the types of SS, investigated various methods of ESA identification and classification, soil combinations, submitted comments on the methods and ways of soil maps generalization, etc.

To study the genetic and geometric structure of the study area, materials of large-scale soil surveys in the scale of 1:10,000 by Lviv branch of "Ukrzemproekt" in 1995, as well as medium and large-scale topographic maps were used. ESA was assumed to be the smallest area of soil, which in this scale can be marked on the map as a separate contour (lowest classification unit type, kind). In studying the soil structure of Mykolaiv-Horodok Upland, we used methods for the identification (natural-cartometric, relief sculpture, quality-genetic) and interpretation (statistical cartometric, functional and analytical) of the soil structure. In particular, in 20142015, natural-cartometric work on field clarification of the boundaries of some soil contours, primarily of eroded characteristics of background soil of the research area, was conducted.

To characterize ESA of the key area natural-cartometric method was used, it makes it possible to determine the parameters of the soil structure and obtain quantitative indicators for the key ESA parameters, which are ESA composition and area ratio, complexity, fractionality, breakdown, heterogeneity and contrast ratio.

There are several dominant soils types in the area of investigation such as sod-podzolic, lightgrey forests, grey forests, dark-grey podzolized and chernozems podzolized. The biggest amount of ESA belongs to subtypes of type dark-grey podzolized soils in the Solonka study area.

The sod-podzolic soils covered south-west part of the study area, there are $11 \mathrm{ESA}$, representing $3.58 \%$ of the total area of the Solonka study area. The ESA of sod-podzolic soils is differentiated by granulometric parcels size. Seven of ESA were formed by sandy glacial sediments, and the rest 4 are subsandy. In addition, areas of sod-podzolic soils are differentiated, on the highest level of classification, by sod-light podzolic and sod-mean podzolic. On the lowest level of classification sod-podzolic soils has been divided by various eroded degrees.

Subtype of light-gray forest soils is represented by 6 ESA, which are located in the southern part and occupy a relatively small area - 251.61 hectares or $3.97 \%$ of the total study area. These areas are represented by eroded and modal soils on the lowest level of taxonomy. The light-gray forest soils are not differentiated by granulometric size, they are slightly coarse silty clayey. It should be noted that $2 / 3$ of this soils was formed on limestone and it can be reachable on the depth of 1.0-1.5 m. 
The morphometric properties of ESA within Solonka study area

\begin{tabular}{|c|c|c|c|c|c|c|c|c|c|c|c|}
\hline \multirow[b]{2}{*}{$\begin{array}{l}\text { Soil } \\
\text { Index }\end{array}$} & \multirow[b]{2}{*}{ Full name of the soil } & \multirow{2}{*}{ 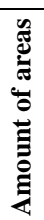 } & \multicolumn{5}{|c|}{ Area, hectares } & \multirow[b]{2}{*}{$\begin{array}{l}\hat{0} \\
\hat{0}\end{array}$} & \multicolumn{3}{|c|}{$\mathbf{C D}^{2}$} \\
\hline & & & 퓽 & 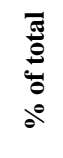 & $\stackrel{\searrow}{\leftrightarrows}$ & 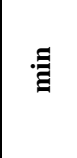 & 范 & & 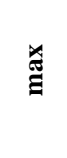 & 罪 & 楚 \\
\hline $2 \mathrm{~F}$ & $\begin{array}{l}\text { Sod-mean podzolic gleyish sandy soils } \\
\text { on fluvioglacial sediments }\end{array}$ & 4 & 86,60 & 1,37 & 45,03 & 2,65 & 21,70 & 0,75 & 1,34 & 1,05 & 1,66 \\
\hline $3 F$ & $\begin{array}{l}\text { Sod-mean podzolic gleyish weakly } \\
\text { washed sandy soils on fluvioglacial } \\
\text { sediments }\end{array}$ & 3 & 39,61 & 0,62 & 21,49 & 6,16 & 13,20 & 0,42 & 1,45 & 1,27 & 1,69 \\
\hline $4 \mathrm{~F}$ & $\begin{array}{l}\text { Sod-mean podzolic gleyish meanly } \\
\text { washed subsandy soils on fluvioglacial } \\
\text { sediments }\end{array}$ & 2 & 16,86 & 0,27 & 9,12 & 7,74 & 8,43 & 0,08 & 1,55 & 1,39 & 1,70 \\
\hline 6 & $\begin{array}{l}\text { Dark-grey podzolized gleyish subsandy } \\
\text { soils on sandy subclays }\end{array}$ & 2 & 62,08 & 0,98 & 40,89 & 21,19 & 31,04 & 0,32 & 1,50 & 1,37 & 1,63 \\
\hline 7 & $\begin{array}{l}\text { Dark-grey podzolized gleyish meanly } \\
\text { washed subsandy soils on sandy subclays }\end{array}$ & 2 & 10,88 & 0,17 & 7,00 & 3,88 & 5,44 & 0,29 & 1,75 & 1,63 & 1,87 \\
\hline 8L/ek & \begin{tabular}{|l|} 
Light-grey forests gleyish slightly \\
coarse silty clayey soils on loess-like \\
subclay, that streched by limestones \\
from $1.0-1.5$ meters deep
\end{tabular} & 3 & 155,41 & 2,45 & 129,68 & 6,61 & 51,80 & 1,00 & 1,49 & 1,25 & 1,76 \\
\hline 10L/ek & $\begin{array}{l}\text { Grey forests gleyish sandy-slighly } \\
\text { clayey soils on loess-like subclay, that } \\
\text { streched by limestones from 1.0-1.5 } \\
\text { meters deep }\end{array}$ & 2 & 142,87 & 2,25 & 135,66 & 7,21 & 71,44 & 0,90 & 2,05 & 1,26 & 2,85 \\
\hline 11L/ek & $\begin{array}{l}\text { Grey forests gleyish weakly washed } \\
\text { sandy-slighly clayey soils on loess-like } \\
\text { subclay, that stretched by limestones } \\
\text { from } 1.0-1.5 \text { meters deep }\end{array}$ & 2 & 156,07 & 2,46 & 137,36 & 18,71 & 78,04 & 0,76 & 1,79 & 1,69 & 1,88 \\
\hline 12L/ek & $\begin{array}{l}\text { Grey forests gleyish, meanly washed } \\
\text { with heavily washed } 30 \% \text {, slightly } \\
\text { coarse silty clayey soils on loess-like } \\
\text { subclay, that streched by limestones } \\
\text { from } 1.0-1.5 \text { meters deep }\end{array}$ & 6 & 193,90 & 3,06 & 85,04 & 4,63 & 32,32 & 0,65 & 1,84 & 1,22 & 3,59 \\
\hline 14L/ek & $\begin{array}{l}\text { Dark-grey podzolized gleyish weakly } \\
\text { washed slightly coarse silty clayey soils } \\
\text { on loess-like subclay, that stretched by } \\
\text { limestones from } 1.0-1.5 \text { meters deep }\end{array}$ & 4 & 241,88 & 3,81 & 147,71 & 2,01 & 60,47 & 0,89 & 1,79 & 1,17 & 2,20 \\
\hline 15L/ek & $\begin{array}{l}\text { Dark-grey podzolized gleyish meanly } \\
\text { washed with heavily washed } 30 \% \text {, } \\
\text { slightly coarse silty clayey soils on } \\
\text { loess-like subclay, that stretched by } \\
\text { limestones from } 1.0-1.5 \text { meters deep }\end{array}$ & 3 & 229,26 & 3,62 & 151,05 & 8,96 & 76,42 & 0,65 & 1,96 & 1,11 & 3,52 \\
\hline $16 \mathrm{~L}$ & $\begin{array}{l}\text { Light-grey forests gleyed slightly coarse } \\
\text { silty clayey soils on loess-like subclay }\end{array}$ & 2 & 67,78 & 1,07 & 45,95 & 21,83 & 33,89 & 0,36 & 1,69 & 1,51 & 1,87 \\
\hline $17 \mathrm{~L}$ & $\begin{array}{l}\text { Grey forests gleyish slightly coarse silty } \\
\text { clayey soils on loess-like subclay }\end{array}$ & 5 & 116,67 & 1,84 & 66,82 & 1,75 & 23,33 & 0,75 & 1,54 & 1,03 & 2,40 \\
\hline $18 \mathrm{~L}$ & $\begin{array}{l}\text { Grey forests gleyish weakly washed } \\
\text { slightly coarse silty clayey soils on } \\
\text { loess-like subclay }\end{array}$ & 3 & 82,42 & 1,30 & 69,04 & 5,76 & 27,47 & 1,01 & 1,52 & 1,44 & 1,64 \\
\hline
\end{tabular}

${ }^{1}$ CDSO - The coefficient of the differentiation of the soil outlines.

${ }^{2} \mathbf{C D}$ - The coefficient of the dismemberment. 


\begin{tabular}{|c|c|c|c|c|c|c|c|c|c|c|c|}
\hline \multicolumn{12}{|c|}{ Continuation of the table } \\
\hline $20 \mathrm{~L}$ & $\begin{array}{l}\text { Grey forests gleyish meanly washed with } \\
\text { heavily washed } 50 \% \text {, slightly coarse } \\
\text { silty clayey soils on loess-like subclay }\end{array}$ & 3 & 45,57 & 0,72 & 34,73 & 3,65 & 15,19 & 0,86 & 2,68 & 1,88 & 3,13 \\
\hline $21 \mathrm{~L}$ & $\begin{array}{l}\text { Grey forests heavily gleyish slightly } \\
\text { coarse silty clayey soils on loess-like } \\
\text { subclay }\end{array}$ & 5 & 151,36 & 2,39 & 47,25 & 15,23 & 30,27 & 0,29 & 1,55 & 1,26 & 1,81 \\
\hline $22 \mathrm{~L}$ & $\begin{array}{l}\text { Grey forests gleyed slightly coarse silty } \\
\text { clayey soils on loess-like subclay }\end{array}$ & 7 & 704,55 & 11,11 & 248,95 & 8,21 & 100,65 & 0,83 & 2,13 & 1,37 & 2,95 \\
\hline $23 \mathrm{~L}$ & $\begin{array}{l}\text { Grey forests gleyed weakly washed } \\
\text { slightly coarse silty clayey soils on } \\
\text { loess-like subclay }\end{array}$ & 5 & 132,32 & 2,09 & 47,19 & 12,06 & 26,46 & 0,39 & 2,25 & 1,58 & 3,18 \\
\hline $25 \mathrm{~L}$ & $\begin{array}{l}\text { Dark-grey podzolized gleyish slightly } \\
\text { coarse silty clayey soils on loess-like } \\
\text { subclay }\end{array}$ & 19 & 627,56 & 9,90 & 152,39 & 0,08 & 33,03 & 0,78 & 1,54 & 1,04 & 2,56 \\
\hline $26 \mathrm{~L}$ & $\begin{array}{l}\text { Dark-grey podzolized gleyish weakly } \\
\text { washed slightly coarse silty clayey soils } \\
\text { on loess-like subclay }\end{array}$ & 12 & 405,36 & 6,39 & 108,99 & 8,42 & 33,78 & 0,57 & 2,23 & 1,24 & 3,02 \\
\hline $27 \mathrm{~L}$ & $\begin{array}{l}\text { Dark-grey podzolized gleyish meanly } \\
\text { washed slightly coarse silty clayey soils } \\
\text { on loess-like subclay }\end{array}$ & 4 & 47,32 & 0,75 & 21,90 & 5,30 & 11,83 & 0,48 & 1,84 & 1,15 & 2,69 \\
\hline $28 \mathrm{~L}$ & $\begin{array}{l}\text { Dark-grey podzolized gleyish, meanly } \\
\text { washed with weakly washed } 30 \% \text {, } \\
\text { slightly coarse silty clayey soils on } \\
\text { loess-like subclay }\end{array}$ & 6 & 184,16 & 2,90 & 59,78 & 1,44 & 30,69 & 0,67 & 2,16 & 1,25 & 3,31 \\
\hline $29 \mathrm{~L}$ & $\begin{array}{l}\text { Chernozems podzolized gleyish slightly } \\
\text { coarse silty clayey soils on loess-like } \\
\text { subclay }\end{array}$ & 12 & 716,74 & 11,30 & 177,90 & 8,46 & 59,73 & 0,70 & 1,77 & 1,20 & 2,28 \\
\hline $30 \mathrm{~L}$ & $\begin{array}{l}\text { Chernozems podzolized gleyish weakly } \\
\text { washed slightly coarse silty clayey soils } \\
\text { on loess-like subclay }\end{array}$ & 14 & 411,25 & 6,49 & 80,83 & 2,60 & 29,38 & 0,94 & 2,08 & 1,13 & 3,68 \\
\hline $31 \mathrm{~L}$ & $\begin{array}{l}\text { Chernozems podzolized gleyish meanly } \\
\text { washed slightly coarse subclayey on } \\
\text { loess-like subclay }\end{array}$ & 7 & 79,22 & 1,25 & 41,07 & 1,81 & 11,32 & 0,86 & 2,18 & 1,33 & 3,88 \\
\hline 32L & $\begin{array}{l}\text { Chernozems podzolized gleyish heavily } \\
\text { washed slightly coarse mean clayey on } \\
\text { loess-like subclay }\end{array}$ & 3 & 32,36 & 0,51 & 23,62 & 2,02 & 10,79 & 0,79 & 1,68 & 1,15 & 2,30 \\
\hline 33L & $\begin{array}{l}\text { Chernozems podzolized washed in, } \\
\text { slightly coarse silty clayey soils on } \\
\text { loess-like subclay }\end{array}$ & 7 & 35,56 & 0,56 & 12,39 & 0,91 & 5,08 & 0,51 & 2,11 & 1,23 & 3,11 \\
\hline 34al-d & $\begin{array}{l}\text { Meadows gleyed washed in, slightly } \\
\text { coarse silty clayey soils on alluvium- } \\
\text { deluvium sediments }\end{array}$ & 12 & 133,58 & 2,11 & 23,71 & 2,50 & 11,13 & 0,41 & 2,78 & 1,30 & 4,07 \\
\hline 35 al-d & $\begin{array}{l}\text { Meadows calcareous slightly coarse } \\
\text { silty clayey soils on alluvium-deluvium } \\
\text { sediments }\end{array}$ & 4 & 50,83 & 0,80 & 24,78 & 6,05 & 12,71 & 0,49 & 2,27 & 1,70 & 2,94 \\
\hline 36al-d & $\begin{array}{l}\text { Meadows calcareous stratified slightly } \\
\text { coarse silty clayey soils on alluvium- } \\
\text { deluvium sediments }\end{array}$ & 4 & 58,55 & 0,92 & 24,74 & 6,65 & 14,64 & 0,50 & 2,24 & 1,51 & 2,94 \\
\hline 37al-d & $\begin{array}{l}\text { Meadow-boggy washed in, coarse silty } \\
\text { clayey soils on alluvium-deluvium } \\
\text { sediments }\end{array}$ & 13 & 145,44 & 2,29 & 36,93 & 1,00 & 11,19 & 0,73 & 2,48 & 1,03 & 4,06 \\
\hline $\begin{array}{l}39-40 \\
\text { T/al-d }\end{array}$ & $\begin{array}{l}\text { Peats bog lawland, mediumdepth, } \\
\text { shallowly and deeply hidden, medium } \\
\text { decomposed, sedge on alluvium- } \\
\text { deluvium sediments }\end{array}$ & 5 & 54,84 & 0,39 & 16,69 & 0,08 & 11,47 & 0,34 & 2,22 & 1,07 & 2,87 \\
\hline 41 & Bog-mud soils of karst sinks & 35 & 14,69 & 0,23 & 1,19 & 0,12 & 0,42 & 0,46 & 1,11 & 1,04 & 1,78 \\
\hline
\end{tabular}


Almost the third part of study (29.81\%) are is covered gray forest soils where 41 ESA is selected. According to granulometric size, the $15.8 \%$ of soils are sandy-loamy, $84.2 \%$ - siltyloamy. These areas are represented by eroded and modal soils on the lowest level of taxonomy. Also, there are 22 ESA of slightly gleyish and 5 ESA of gleyish and 14 ESA of hard gleyish soils caused by different annual moisture volume and geomorphological component. It should be noted that 10 of 41 ESA were formed on limestone.

As noted above, the most widespread soils within the study area are dark-gray podzolized soils. There are 53 ESA or $31.1 \%$ of the study area. The ESA are differentiated by granulometric content, eg only $3.7 \%$ belongs to sandy soils, and the rest $96.3 \%$ - to silty-loam soils. More than half (56.72 \%) of this soils are eroded and 8 ESA underlayed by limestone.

There are 43 ESA (20.11\%) of chernozems podzolized in the study area. The biggest part (97.46 \% area) are characterized by silty-loam granulometric size, and only eroded units are more silty. All ESA of chernozems podzolized were formed on the loam loess.

Except zonal types of soils there are azonal as well. In particular, the areas of meadows gleyed, meadows calcareous, meadow-boggy, bog-mud and peat soils were identified. They occupy $9.46 \%$ of the study area in total.

The ESA of meadows gleyed, meadows calcareous and meadow-boggy soils distributed within the gullies and ravines of the study area. According to granulometric size the $45.81 \%$ of them heavy silty-loam and 54.29 - silty-loam. All ESA formed on alluvial-delluvial sediments.

There are 5 ESA of peatlands occupied only $0.86 \%$ of the Solonka study area. They are sedge type according to the floristic composition.

Analysing the structure of the soil cover of the Solonka study area we identified 249 ESA. Our next objectives were to analyse morphological and cartographic parameters of these ESA.

Starting from Sod-podzolic soils we identified several sybtypes of this soils such as 4 areas of sod-mean podzolic gleyish meanly washed subsandy soils, 3 areas of sod-mean podzolic gleyish weakly washed sandy soils, 2 areas sod-mean podzolic gleyish meanly washed subsandy soils, one area of sod-light podzolic subsandy soil and 1 area sod-mean podzolic gleyed. All these types formed on fluvioglacial sediments.

The differences in sod-podzolic ESA varied in range from 2.65 to 45.03 hectares, the average area is 21.7 hectares. The degree of ESA areas variability we evaluated using the coefficient of the differentiation of the soil outlines (CDSO) and methods of variation statistics (coefficient of variability - V). The area of sod-podzolic sandy ESA characterized by considerable variability (CDSO $=0.75 ; \mathrm{V}=91.21 \%$ ). Shape, degree of tortuosity and elongation limits was estimated using the coefficient of the dismemberment (CD). The degree of dismemberment of analysed ESA belonging to undivided $(C D=1.34)$. Areas of sod-mean podzolic gleyish weakly washed sandy soils ESA are less differentiated (Smin $=6.16$ hectares; Smax $=13.2$ hectares, CDSO $=0.42$ ), the average rate of dismemberment coefficient is 1.45 , the variation of dismemberment coefficient is quite significant - $58.64 \%$. The ESA of sodmean podzolic gleyish meanly washed subsandy soils is slightly differentiated (7.74 and $8.43 \mathrm{ha}$ ) and CDSO is 0.08. The degree of its dismemberment - undifferentiated, CD = 1.55. The morphological form of most sod-podzolic ESA is extended.

Light-grey forests gleyish slightly coarse silty clayey soils on loess-like subclay, that stretched by limestones from 1.0-1.5 meters deep characterized by considerable variability sizes from 6.61 to 51.8 hectares $(\mathrm{V}=130.86 \%)$. The degree of differentiation of soil outlines is 1.00 , which indicates a significant deviation from considered average of areas. The ESA 
contours are undifferentiated ( $C D=1.49)$, the average variability index is $16.96 \%$. Light-grey forests gleyed slightly coarse silty clayey soils on loess-like subclay have a very little variability in size $(S \operatorname{smin}=21.83$ hectares; Smax $=33.89$ hectares; $\quad$ CDSO $=0.36)$, and the low dismemberment coefficient (CD $=1.69)$ and its low variability $(15 \%)$ as well.

As mentioned above, areas of gray forest soils within the study area occupy a large area. They are differentiated by the erosion degree and granulometric size. In addition, they are characterized by considerable variability ranges of contour sizes - from 1.75 to 248.95 ha $(\mathrm{V}=39.31-131.09)$. The degree of differentiation of the soils outlines varies from 0.29 to 1.01 . The ESA morphological forms are mainly elongated or asymmetrical. In terms of coefficient of boundaries dismemberment, the ESA characterized by a predominance of undifferentiated or slightly dissected. The value of the dismemberment coefficient varies in small range $(\mathrm{CD}=1.52-2.68)$.

The large part of Solonka study area belong to dark-grey podzolized soils. The ESA size changed considerably $-0.08-163.6$ hectares. The degree of differentiation of soil outlines and coefficient of variability is quite considerable (CDSO $=0.48-0.89$; V $=40.55-114.11 \%$ ). Based on dismemberment coefficient the ESA can be considered as undifferentiated or slightly dissected $(C D=1.50-2.23)$. The ESA morphological shape varied: elongated, linear, symmetric or asymmetric. The average area of the not eroded soils is 75.89 hectares, slightly eroded -47.13 , medium eroded -36.84 hectares. We can conclude that there is a correlation between decreasing of the area and level of erosion. The same trend can be noticed with the distribution of average CD values (not eroded -1.52 , slightly eroded -1.79 , medium eroded 2.01), due to the growth of borders curling in eroded soils.

The chernozems podzolized covered only small areas of the central and northern parts of study area. The same as for the dark-grey podzolized the ESA of chernozems podzolized have tendency to reduce the average areas from not eroded (59.73 hectares) to heavy eroded and deposited (10.79 and 5.08 hectares respectively). Without exception, all ESA of chernozems podzolized areas are characterized by significant level of variability areas (CDSO $=0.51-0.94$; $\mathrm{V}=72.98-122.93)$. As the degree of boundaries dismemberment the ESA of not eroded heavy eroded belongs to undivided ( $C D=1.68-1.77$ ), slightly and medium eroded, deposited - to slightly divided (CD = 2.08-2.18). The morphological shapes of ESA characterized by stretch and asymmetric shovel-type forms.

The areas of meadows gleyed, meadows calcareous, bog-mud and meadow-boggy soils and peats were created in the hydromorphic depressions, gullies and ravines of Solonka study area. More than two percent of the territory occupied by meadow-boggy washed in coarse silty clayey soils that created on alluvium-deluvium sediments (12 ESA). The ESA size characterized by considerable variation, from 2.5 to 23.71 hectares, the dismemberment coefficient varies from 1.3 to 4.06 . The vast majority of these ESA characterized by elongated and asymmetrical shapes. The medium and large areas (6.05-24.78) predominate for the meadows calcareous. The degree of differentiation of soil outlines and coefficient of variability are significant (CDSO $=0.49-0.50 ; \mathrm{V}=59.54-68.13 \%$ ). The dismemberment coefficient is 2.24-2.27 what characterized these outlines as medium sliced. It's outlines are isomorphic and elongated. Regarding the bog-mud and meadow-boggy soils, their average size varies widely, from 0.42 to 35.46 hectares, which is reflected in the high coefficient of variability $\mathrm{V}=57.36-93.91 \%$. According to the average value of the ESA dismemberment coefficient they belongs to slightly and medium sliced $(C D=1.11-2.48)$. The morphological forms of the bog-mud soils characterized by symmetrical and oval forms, meadow-boggy is characterized 
by asymmetrical, elongated shapes. In addition, within study area we found 5 contours of peatlands. Their size varies widely (0,08-16,69 ha), dismemberment coefficient $\mathrm{CD}=1.87-2.22$, coefficient of variability is not high $\mathrm{V}=37.79-40.96 \%$.

According to the existing classification, the ESA boundaries type can be sharply, clearly and not clearly defined. Studying the character of ESA boundaries of Solonka study area we found that for most of them characterized by clearly and not clearly defined. The clearly defined boundaries belong to the grey forests, dark-grey podzolized and chernozems podzolized, the not clearly defined borders - eroded soils. Sharply defined borders inherent to the various hydromorphic soils. To this type, we can also include the boundaries between areas adjacent to the ravines and gullies: the boundaries between the sod-podzolic and grey forests and sodpodzolic and bog-mud soils, etc.

What is the main ecological factors caused of the different types of ESA boundaries within Solonka study area? First, spatial distribution of rocks, especially carbonated sediments played big role in differences between ESA. In addition, differences in humectation and erosion caused creation of ESA with different level of gleying and erosion processes.

To conclude, according to the national classification the soil cover formed with the smallest mapping units - elementary soil area. These ESA form the micro and mesostructure of soil microcombinations and mesostructures. The represented analysed data and results of the field, cartographic and statistical analysis should be the basement for further evaluation of the higher levels of soil cover structure, e.g. soil combinations and soil cover in general.

\section{СПИСОК ВИКОРИСТАНОЇ ЛІТЕРАТУРИ}

1. Гаськевич $O$. В. Роль антропогенного чинника у формуванні структури грунтового покриву Гологоро-Кременецького горбогір'я // Наук. зап. Терн. держ. пед. ун-ту. Сер. геогр. 2004, № 2. Ч. 1. С. 138-143.

2. Годельман Я. М. Неоднородность почвенного покрова и использование земель М. : Наука, 1981. 202 с.

3. Позняк С. П., Красєха С. Н., Кim М. Г. Картографування грунтового покриву. Львів : Видавничий центр ЛНУ імені Івана Франка, 2003. 500 с.

4. Прасолов Л. И. Генезис, география и картография почв. М. : Наука, 1978. 263 с.

5. Радзій В. Ф. Генетико-геометрична будова структури грунтового покриву Волинської височини // Вісн. Львів. ун-ту. Сер. геогр. 2000. Вип. 26. С. 104-107.

6. Радзій В. Ф., Позняк С. П. Структура грунтового покриву Волинської височини. Луцьк : Вежа, 2009. 206 с.

7. Строганова M. М. Структура почвенного покрова и почвенная картография. 2011. URL: http://soil.msu.ru/kaf-geografia/1593-1177.

8. Фридланд В. М. Проблемы географии, генезиса и классификации почв. М. : Наука, 1986. $243 \mathrm{c}$.

9. Фридланд В. М. Структура почвенного покрова и методы ее изучения. М. : Мысль, 1973. $257 \mathrm{c}$. 


\section{REFERENCES}

1. Haskevych, O. V. (2004). The role of human factor in determining the structure of soil of Holohory-Kremenets Hill Ridge. Scientific notes of Ternopil' State Pedagogical University. Series Geography, 2, 138-143 (in Ukrainian).

2. Godelman, Ia. M. (1981). The heterogeneity of soil cover and land use. Moscow: Science, 202 pp. (in Russian).

3. Poznyak, S. P., Krasyekha, Y. N., \& Kit, M. H. (2003). Mapping of the soil cover. Lviv: Publishing centre of Lviv Ivan Franko National University, 500 pp. (in Ukrainian).

4. Prasolov, L. I. (1978). Genesis, geography and soil cartography. Moscow: Science, 283 pp. (in Russian).

5. Radziy, V. F. (2000). Henetyko-heometrychna budova struktury gruntovoho pokryvu Volynskoi vysochyny. Visnyk of the Lviv University. Series Geography, 26, 104-107 (in Ukrainian).

6. Radziy, V. F. (2009). The structure of the soil cover of Volyn Upland. Lutsk, 206 pp. (in Ukrainian).

7. Stroganova, M. N. (2011). The structure of the soil cover and the soil mapping. Moscow. Retrieved February 6, 2016, from soil.msu.ru/kaf-geografia/1593-1177 (in Russian).

8. Fridland, V. M. (1986). Problems of geography, genesis and classification of the soils. Moscow: Science, 243 pp. (in Russian).

9. Fridland, V. M. (1973). The structure of the soil cover and the methods of its study. Moscow: Mysl, 257 pp. (in Russian).

Стаття: надійшла до редакиії 09.09.2016

доопрацььована 12.10.2016

прийнята до друку 24.11.2016

\section{ЕЛЕМЕНТАРНІ ГРУНТОВІ АРЕАЛИ МИКОЛАЇВСЬКО-ГОРОДОЦЬКОГО ОПІЛЛЯ}

\section{Микола Федотіков, Тарас Ямелинець} Львівський національний університет імені Івана Франка,
вул. П. Дорошенка, 41, 79007, м. Львів, Україна

Під час вивчення структури грунтового покриву Миколаївсько-Городоцького Опілля використано методи виявлення (натурно-картометричний, пластики рельєфу, якісно-генетичний) та інтерпретації (статистико-картометричний, функціонально-аналітичний) структури грунтового покриву. Безпосередньо для характеристики елементарних грунтових ареалів ключової ділянки використано натурно-картометричний метод, що дає змогу визначити параметри структури грунтового покриву й отримати кількісні показники для основних параметрів, якими $є$ склад та співвідношення площ елементарних грунтових ареалів, складність, дрібність, розчленування, неоднорідність та контрастність.

Наведено результати вивчення якісних та кількісних характеристик елементарних грунтових ареалів Миколаївсько-Городоцького Опілля. За допомогою коефіцієнта ступеня диференціації грунтових контурів та методів варіаційної статистики визначено й проаналізовано ступінь 
мінливості площ елементарних грунтових ареалів. Досліджено форму, ступінь звивистості та витягнутості меж ареалів за допомогою коефіцієнта розчленування. Вивчено характер меж елементарних грунтових ареалів на території дослідження. Виявлено основні особливості залежності меж цих ареалів від різних екологічних чинників. Простежено певні закономірності зміни основних параметрів елементарних грунтових ареалів, що формують структуру грунтового покриву Миколаївсько-Городоцького Опілля.

Ключові слова: елементарний грунтовий ареал, структура грунтового покриву, коефіцієнт варіації грунтових контурів, коефіцієнт ступеня диференціації грунтових контурів, коефіцієнт розчленування меж ареалів. 